\title{
Comparison of Fecal Indicator Bacterial Counts in Shellfish Harvested from Kedah, Penang and Perak Pre and Post-Tsunami
}

\author{
Wan Norhana, N. ${ }^{*}$, Mohd Nor Azman, A. and Ramlah, A. M. \\ Fisheries Research Institute, 11960 Batu Maung, Pulau Pinang \\ Email: wannorhana@yahoo.com
}

\begin{abstract}
The objectives of this paper are to examine the level of fecal indicator bacterial counts (Fecal Coliform (FC) and Escherichia coli (EC)) in shellfish harvested from Penang, Perak and Kedah after the tsunami and to compare the mean FC and EC in shellfish from the three states pre and post-tsunami. The data used in this paper were obtained from the Department of Fisheries' Sanitary and Photosanitary (SPS) Program which monitored the shellfish culture areas around the Peninsular Malaysia regularly. Data were analysed using SPSS (Version 11.5). Generally more than $50 \%$ of the samples collected from each states after the tsunami complied to the microbiological safety guidelines $(<230 \mathrm{MPN} / 100 \mathrm{~g}$ EC or $<300 \mathrm{MPN} / 100 \mathrm{~g}$ FC). Classification of shellfish produced from the three states after the tsunami shows that it fall into Class B which indicates that shellfish produced in these areas are not for raw consumption and can only be placed in the market after depuration or relaying. Statistical analysis, showed no significant difference $(p>0.05)$ between the mean FC and EC counts in Penang, Perak and Kedah pre and post-tsunami.
\end{abstract}

Keywords: Fecal Indicator, shellfish waters, pre, post tsunami

\section{INTRODUCTION}

The tsunami of $26^{\text {th }}$ December 2004 had a devastating impact on the fishery sector in many countries of the Indian Ocean. In Malaysia alone, 7,721 fishers were affected and 3,625 units of fishing vessels estimated at over RM 28.0 million were destroyed. Meanwhile 232 fish farmers lost around RM 23.9 million worth of facilities and standing crop (Anon., 2005a). In addition, there was also 'negative consumer reaction' and demand of fish had dropped due to the fear of contamination in the post tsunami days.

Does the recent tsunami has an effect on seafood safety and quality? Food and Agriculture Organisation (FAO) claimed that there is no evidence, epidemiological or of any other nature, of an increased risk of fish and seafood-borne illnesses in the affected regions (Anon., 2005b). Surveys on seafood safety and quality carried out immediately after the tsunami by the Fisheries Research Institute, Batu Maung have found that there is no significant increase in fecal indicator bacterial counts and specific pathogens (Salmonella sp, Vibrio parahaemolyticus, Vibrio cholerae) in the seafood samples collected (Wan Norhana et al., 2005). Pilot study conducted by the Central Institute of Fisheries Technology (CIFT), Kochi, India has also indicated that seafood from tsunami hit area is safe for consumption (The Hindu Online Edition of India's National Newspaper). However, the World Health Organisation (WHO) had warned that damaged wastewater and sanitation system due to the tsunami might leak into fishing ground, aquaculture ponds and shellfish bed thus leading to viral, bacterial and parasitic intestinal infections.

$\overline{{ }^{*} \text { Corresponding author }}$
Has the recent tsunami destroyed or damaged our sewage system thus causing seepage of sewage into fishing ground, aquaculture ponds and shellfish bed? We planned to use data from the existing Department of Fisheries' (DOF) Marine Sanitary and Phytosanitary (SPS) Program to determine this.

The DOF Marine SPS monitoring program has been developed with the purpose of ensuring public health as well as to fulfill the requirements of the World Trade Organisation's (WTO) agreement. The main objective of this program is to ensure that fish/shellfish are harvested from safe areas and of high quality for human consumption. Under this program, samplings of fish/shellfish/water are carried out from a total of thirty sampling sites comprising of landing ports/jetties and fisheries waters all over Peninsular Malaysia. For the purpose of this paper, we only concentrate on shellfish since the bacterial contamination in them is closely related to the cleanliness of the water in which they are grown. This is due to their manner of feeding process which actively concentrate fecal bacteria from surrounding seawater. Besides that contamination in shellfish is riskier because they are usually eaten whole (including guts) raw or half-cooked.

This paper attempts to examine the level of fecal indicator bacterial counts (Fecal Coliform (FC) and Escherichia coli (EC)) in shellfish harvested in Penang, Perak and Kedah after the tsunami and to compare the mean FC and EC in shellfish from the three states before and after tsunami. The null hypotheses is that there is no difference in mean FC and EC counts within this period. 


\section{MATERIALS AND METHODS}

For the purpose of this paper only sampling stations located in the North of Peninsular were included. Figure 1 shows the map of sampling stations and type of shellfish collected. Under this program, shellfish are collected 4-6 times per year depending on the historical data on the level of fecal pollution in that area. Cockles from Seberang Perai, Penang for example were collected 6 times per year because of the high fecal contamination observed in them from previous years. Meanwhile cockles from Perak and Kedah as well as carpet clams from Kedah were collected 4 times per year. This paper will use the data obtained from March-July of 2004 and 2005.

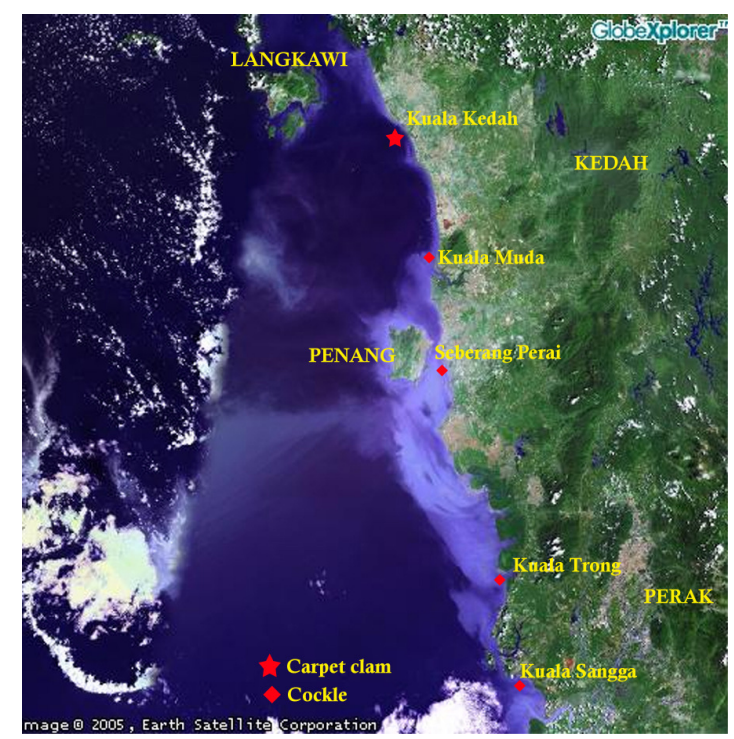

Figure 1: Sampling stations involved in this survey

The number of samples collected every time at each location is $8(n=8)$. Samples were collected by the state extension officer and put in disposable sterile containers, transported in ice-cooled insulated box, and then brought to the laboratory and analysed within 24 hours of collection.

FC and EC counts were determined by the Most Probable Number (MPN) technique as described in the Compendium of Method for Microbiological Examination of Foods, American Public Health Association (APHA), $3^{\text {rd }}$ Edition, 1992. The recommended levels of EC and FC set by European Committee (Directives 91/492/EEC of 15 July 1991- Laying down the health conditions for the production and the placing on the market of live bivalve molluscs) as illustrated in Table 1 were used as reference to determine the safety levels of shellfish as well as classifying them.

All statistical analysis was carried out using SPSS Software (version 11.5) and counts were transferred to log before being analysed. A non-parametric Wilcoxon Signed Ranks Test was employed to determine the significant difference in pre and post-tsunami data because only a small number of samples were involved $(\mathrm{N}=72)$ and the data obtained was not in normal distribution.

Table 1: EC SHELLFISH DIRECTIVES 91/492/EEC

\begin{tabular}{|c|c|c|c|}
\hline \multicolumn{2}{|c|}{ Classification } & Recommended levels & \multirow{2}{*}{$\begin{array}{l}\text { Outcome } \\
\text { May go direct for } \\
\text { human consumption }\end{array}$} \\
\hline $\mathrm{A}$ & $<230$ & $\begin{array}{l}\text { Less than } 230 \quad E \text {. } \\
\text { coli/100g flesh or } \\
\text { Less than } 300 \text { Fecal } \\
\text { coliform } / 100 \mathrm{~g} \text { flesh }\end{array}$ & \\
\hline B & $<4,600$ & $\begin{array}{l}\text { Less than } 4,600 E \text {. } \\
\text { coli/ } 100 \mathrm{~g} \text { flesh (in } 90 \% \\
\text { of the samples) or } \\
\text { Less than } 6000 \mathrm{Fecal} \\
\text { coliform } / 100 \mathrm{~g} \text { flesh (in } \\
90 \% \text { of the samples) }\end{array}$ & $\begin{array}{l}\text { Must be depurated, } \\
\text { heat treated or } \\
\text { relayed to meet } \\
\text { category } \\
\text { requirement }\end{array}$ \\
\hline $\mathrm{C}$ & $<46,000$ & $\begin{array}{l}\text { Less than } 46,000 \quad E . \\
\text { coli/100g flesh }\end{array}$ & $\begin{array}{l}\text { Must be relayed for } \\
\text { a period of at least } 2 \\
\text { months, followed } \\
\text { where necessary by } \\
\text { treatment in a } \\
\text { purification centre to } \\
\text { meet category } A \\
\text { requirements }\end{array}$ \\
\hline & $\begin{array}{l}\text { e } 60,000 \\
\text { coliform }\end{array}$ & & $\begin{array}{ll}\text { Unsuitable } & \text { for } \\
\text { production } & \\
\end{array}$ \\
\hline
\end{tabular}

\section{RESULTS}

FC and EC counts in cockles from Seberang Perai ranged from 300-24,000 MPN/100g in March 2005. Lower range was observed in samples collected in May $(300-9,300$ MPN/100g) and June (300-400 MPN/100g) in the same year. Maximum counts of FC recorded at 24,000 MPN/100g (80 times higher than safety standard) in Seberang Perai in March 2005. Meanwhile EC counts in the same samples ranged from 300-9,300 MPN/100g in Mac and similarly low counts of EC (0-300 MPN/100g) were also observed in later sampling dates (May and June, 2005).

Low FC counts ranging from $0-400 \mathrm{MPN} / 100 \mathrm{~g}$ and 300-900 MPN/100g were recorded in shellfish from Perak in March and May 2005, respectively. Meanwhile low EC counts were also recorded for the same samples with maximum counts of only $300 \mathrm{MPN} / 100 \mathrm{~g}$ (1.3 times higher than the safety standards). EC was not detected in $88 \%$ of the Perak's samples in March and 63\% in May.

There are two types of shellfish collected from Kedah. Carpet clams from Kuala Kedah and cockles from Kuala Muda. FC range in carpet clams was higher in July 2005 (300-46,000 MPN/100g) as compared to April (300-9,300 $\mathrm{MPN} / 100 \mathrm{~g})$ the same year. However EC counts in July were much lower (0-400 MPN/100g) compared to April (0$7,500 \mathrm{MPN} / 100 \mathrm{~g})$. Cockles from Kuala Muda recorded much lower range of $\mathrm{FC}$ compared to carpet clams on the same date (0-900 MPN/100g) in April) and (300-700 MPN/100g) in July. Similarly low EC counts were recorded in Kuala Muda cockles in April 2005 and EC was not detected in any cockle samples collected in July the same year. 
Table 2 indicates the percentage of compliance to recommended FC and EC levels based on 91/492/EEC Directives. Generally more than $50 \%$ of the samples collected from each states after the tsunami complied to the recommended levels. Shellfish produced from the areas monitored fall into Class B which indicates that they are not for raw consumption and can only be placed in the market after depuration or relaying. The same classification status was given to the same areas in 2004 .

Table 2: Classification of shellfish produced in Penang, Perak and Kedah after tsunami

\begin{tabular}{|c|c|c|c|c|}
\hline \multirow[t]{2}{*}{ Locations } & \multirow[t]{2}{*}{ Months } & \multicolumn{2}{|c|}{$\begin{array}{c}\% \text { of samples } \\
\text { complies to safety } \\
\text { limit }\end{array}$} & \multirow[t]{2}{*}{ Classification } \\
\hline & & $\mathrm{FC}$ & $\mathrm{EC}$ & \\
\hline \multirow{3}{*}{ Penang } & March & 50 & 63 & \multirow{3}{*}{$\mathrm{B}$} \\
\hline & May & 50 & 75 & \\
\hline & June & 88 & 88 & \\
\hline \multirow{2}{*}{ Perak } & March & 88 & 88 & \multirow{2}{*}{$\mathrm{B}$} \\
\hline & May & 75 & 75 & \\
\hline \multirow{2}{*}{ Kedah } & April & 43 & 63 & \multirow{2}{*}{ B } \\
\hline & July & 56 & 93 & \\
\hline
\end{tabular}

Table 3 shows the results of statistical analysis output obtained. The sampling size $\mathrm{N}$ is actually 72 , but the software interpreted the samples with 0 values (where FC and $E C$ are not detected) as missing values. Based on the ranks, mean FC post- tsunami is less than pre-tsunami as the mean negative rank is more than positive. Meanwhile mean EC after tsunami is more than before because the mean for positive rank is higher than negative. However the difference is not significant as the $p$ values for both EC and $\mathrm{FC}$ are more than 0.05 .

Table 3: Results of statistical analysis on FC and EC data pre and post-tsunami

\section{Descriptive statistics}

\begin{tabular}{cccccc}
\hline & N & Mean & $\begin{array}{c}\text { Std. } \\
\text { Deviation }\end{array}$ & Minimum & Maximum \\
\hline $\begin{array}{c}\text { EC pre- } \\
\text { tsunami }\end{array}$ & 38 & 2.57228 & 0.179480 & 2.477 & 3.176 \\
\hline $\begin{array}{c}\text { FC pre- } \\
\text { tsunami }\end{array}$ & 59 & 3.01153 & 0.645430 & 2.477 & 4.663 \\
\hline $\begin{array}{c}\text { EC post- } \\
\text { tsunami }\end{array}$ & 26 & 2.76438 & 0.455645 & 2.477 & 3.968 \\
\hline $\begin{array}{l}\text { FC post- } \\
\text { tsunami }\end{array}$ & 62 & 2.88354 & 0.586285 & 2.477 & 4.663 \\
\hline
\end{tabular}

Ranks

\begin{tabular}{ccccc}
\hline & N & $\begin{array}{c}\text { Mean } \\
\text { Rank }\end{array}$ & $\begin{array}{c}\text { Sum of } \\
\text { Ranks }\end{array}$ \\
\hline EC post-tsunami & Negative Ranks & $3^{\mathrm{a}}$ & 2.83 & 8.50 \\
$\begin{array}{c}- \\
\text { EC pre-tsunami }\end{array}$ & Positive Ranks & $5^{\mathrm{b}}$ & 5.50 & 27.50 \\
& Ties & $7^{\mathrm{c}}$ & & \\
& Total & 15 & & \\
FC post-tsunami & Negative Ranks & $23^{\mathrm{d}}$ & 22.11 & 508.50 \\
FC pre-tsunami & Positive Ranks & $19^{\mathrm{e}}$ & 20.76 & 394.50 \\
& Ties & $9^{\dagger}$ & & \\
\cline { 1 - 2 } & Total & 51 & & \\
\hline
\end{tabular}

${ }^{a}$ EC post-tsunami $<$ EC pre-tsunami

${ }^{b}$ EC post-tsunami > EC pre-tsunami

${ }^{\circ}$ EC post-tsunami $=$ EC pre-tsunami

${ }^{d}$ FC post-tsunami $<$ FC pre-tsunami

e FC post-tsunami > FC pre-tsunami

${ }^{\dagger} \mathrm{FC}$ post-tsunami $=\mathrm{FC}$ pre-tsunami

\section{Test Statistics $\left({ }^{c}\right)$}

\begin{tabular}{ccc}
\hline & $\begin{array}{c}\text { EC post-tsunami - } \\
\text { EC pre-tsunami }\end{array}$ & $\begin{array}{c}\text { FC post-tsunami - } \\
\text { FC pre-tsunami }\end{array}$ \\
\hline $\mathrm{Z}$ & $-1.332^{\mathrm{a}}$ & $-.714^{\mathrm{b}}$ \\
\hline $\begin{array}{c}\text { Asymp. Sig. } \\
\text { (2-tailed) }\end{array}$ & .183 & .475 \\
\hline
\end{tabular}

a Based on negative ranks.

b Based on positive ranks.

${ }^{c}$ Wilcoxon Signed Ranks Test

Meanwhile Figure 2 and 3 show the mean FC and EC counts recorded in the shellfish samples at different months before and after tsunami. Results from the statistical analysis indicated that there was no significant difference $(p>0.05)$ in FC and EC counts by month. Similarly there is also no significant difference $(p>0.05)$ between FC and EC count in the shellfish samples from Penang, Perak and Kedah, pre and post tsunami (Figure 4 and 5).

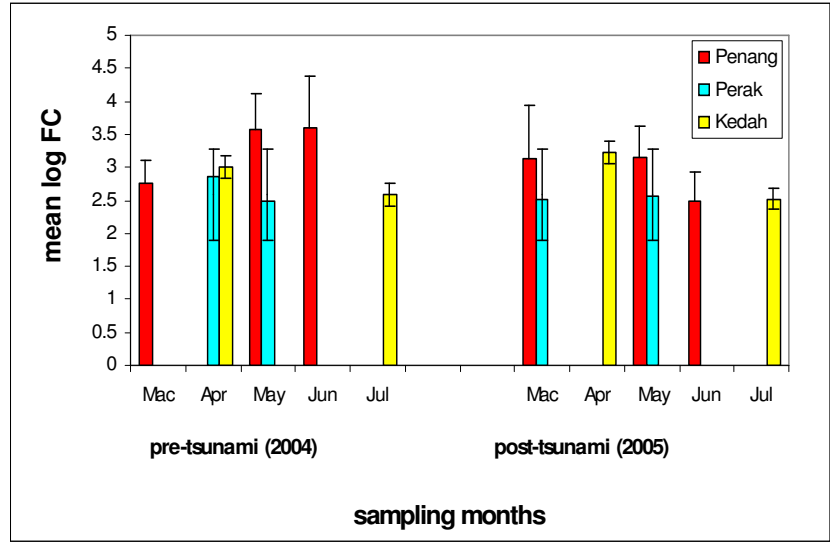

Figure 2: Mean FC counts in different months 


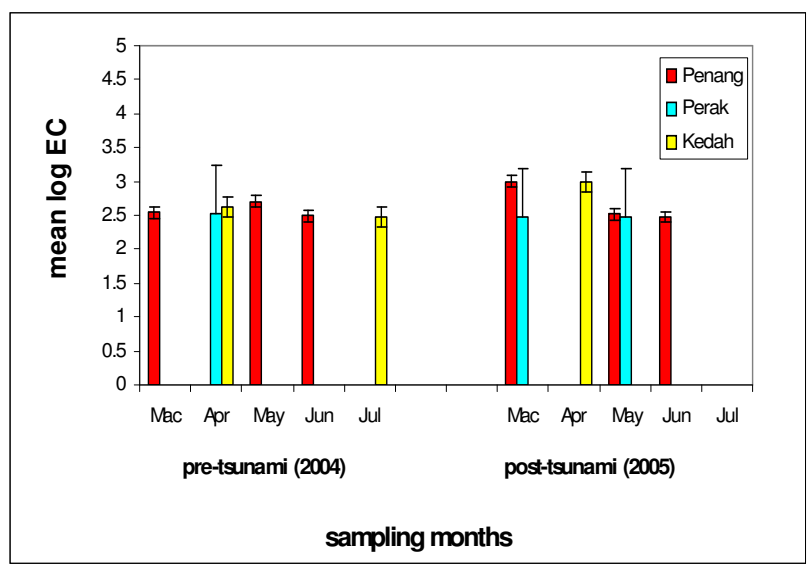

Figure 3: Mean EC counts in different months

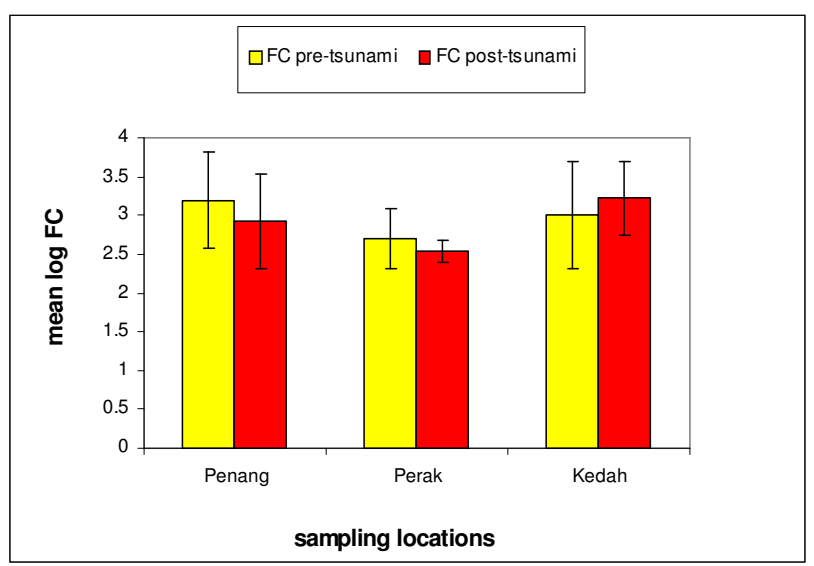

Figure 4: Mean FC counts at different locations

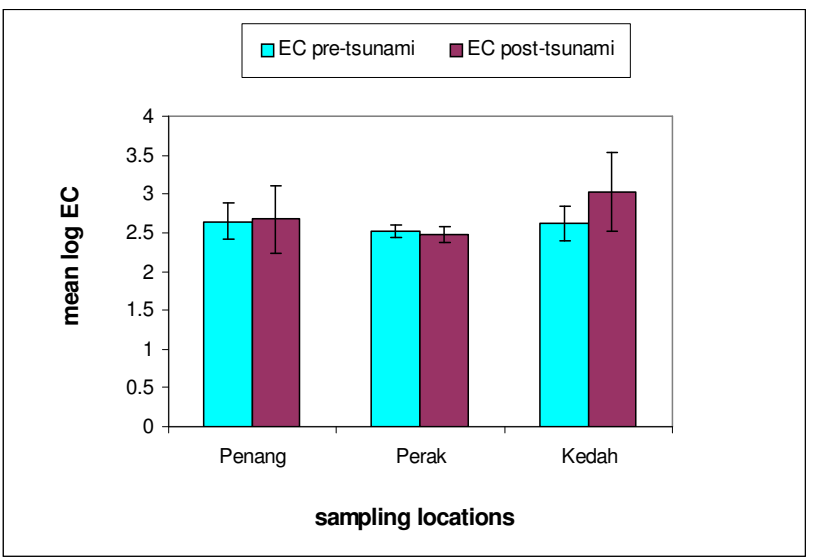

Figure 5: Mean EC counts at different locations

\section{DISCUSSION}

Fecal bacterial pollution of shellfish growing waters can occur from a point or non-point source. Point sources of pollution are contaminants discharged to the aquatic environment through a discrete pipe or ditch, for example discharges of treated or untreated municipal and industrial effluents. Meanwhile non-point sources of pollution are diffused, entering the environment via storm water run-off or groundwater infiltration. Agricultural run-off, urban, residential, recreational or wildlife wastes are examples of non-point source pollution.

The higher counts of FC compared to EC in almost all shellfish samples examined and inconsistent trend of counts suggest that fecal pollution in these particular shellfish waters might originate from various non-point sources of fecal pollution rather than direct discharge or continuous seepage from leaked wastewater or sanitation system which might be due to tsunami.

However high EC counts (as high as the total FC in 3 out of 8 stations) in carpet clams collected from Kuala Kedah in April 2005, suggests that, at this particular place and location, the fecal contamination might originate from human origin.

The range of FC and EC counts obtained from Penang, Perak and Kedah after tsunami was within the range obtained at the same period of time in 2004. It is also within the FC and EC range reported in 2001 and 2002 (Wan Norhana and Nor Ainy, 2004). Previous results from the existing SPS program have shown that cockles from Perak has always had a low count of FC and EC, and this is why only 4 sampling frequencies were suggested for this area. Meanwhile high FC counts in freshly harvested cockles from Seberang Perai, Penang had been reported previously (Ismail, 1991; Wang, 1996; Wan Norhana et al., 1996) thus explaining why more sampling activities were fixed here. Effluents from heavily populated rivers located in this area (Sg. Juru and Sg. Jawi) (Anon., 2001) and drainage from many livestock farms in this area might contribute to the high counts of fecal coliform bacteria.

In conclusion, generally there are no significant increase in fecal bacterial counts in shellfish from Penang, Perak and Kedah. Results from the statistical analysis which indicate that there is no significant difference ( $p>0.05$ ) between the mean FC and EC counts in Penang, Perak and Kedah pre and post-tsunami.

\section{ACKNOWLEDGEMENT}

We would like to thank the Ketua Cawangan Jaminan Kualiti Ikan, Jabatan Perikanan Malaysia as well as the Penang, Perak and Kedah states' extension staff for their help in sampling. We would also like to extend our gratitude to En. Ismail bin Ishak for reading the manuscript and making useful suggestions. Last but not least, thanks to Pn. Faizah, Pn. Azam Hanim and En. Shaik Osman for their assistance in the laboratory.

\section{REFERENCES}

Anon., (2001). Malaysia Environmental Quality Report 2001. Department of Environment, Ministry of Science, Technology and Environment, Malaysia, p .77. 
Anon., (2005a). Impacts of the Tsunami on Fisheries, Aquaculture and Coastal Livelihoods in Malaysia. Consortium to Restore Shattered Livelihoods in Tsunami-Devastated Nation (CONSRN). CONSRN Regional Workshop on Rehabilitation of Fisheries and Aquaculture in Coastal Communities of Tsunam Affected Countries, Bangkok, $28^{\text {th }}$ Feb- ${ }^{\text {st }}$ Mar 2005.

Anon., (2005b). Seafood Safety in the Tsunami Affected Region. FAO Press Release, 1HA/991/SAG/313. $1401 / 2005$.

APHA (American Public Health Association) (1992). Compendium of Methods for the Microbiological Examinations of Food. Third Edition.

ICMSF (International Commission on Microbiological Specification for Food) (1986). In: Microorganisms in Foods. 2. Sampling for Microbiological Analysis: Principles and specific Applications, $2^{\text {nd }}$ ed. University of Toronto Press, Buffolo, New York.

Ismail, H.I. (1991). Bacterial Contamination of the Blood Cockle (Anadara granosa). The Proceedings Seminar on Advances in Fisheries Post-Harvest Technology in Southeast Asia, Singapore, p.230-235.

The Hindu Online Edition of India's National Newspaper. Seafood from tsunami hit area safe for consumption. http:www.hinduonnet.com/2005/01/06/ stories/2005010607530400.html
Wan Norhana, N., Nor Azah, A. and Ismail, I. (1996). A Survey of Fecal Coliforms in Seafood and Seawater in Penang. The Proceedings of Fisheries Research Symposium, Penang, p.365-375.

Wan Norhana, N. and Nor Ainy, M. (2004). Bacteriological Quality of Some Molluscan Shellfish from Growing Waters of Peninsular Malaysia. Malaysian Fisheries Journal 3(1): 27-38.

Wan Norhana, N., Ramlah, A.M., Fisal, A. and Mohd. Nor Azman, A. (2005). A Survey of Indicator Bacterial Levels in Seafood Around Penang. Paper presented at the Workshop on Impact of Tsunami on Fisheries and Coastal Areas, Mac 2005.

Wang, C.W. (1996). Assessment of Microbial Water Quality of Coastal Waters in Southeast Asian countries. In: Viger, I., Ong, K.S., McPherson. C, Millson, N. and Tang, A. Proceedings of the aseancanada technical conference on marine science asean marine environmental management: quality criteria and monitoring for aquatic life and human health protection, Penang, 11: 16-27. 